\title{
AC 2009-1779: INTEGRATING GREEN ENGINEERING INTO A MULTIDISCIPLINARY SEMINAR COURSE
}

\section{David Cottrell, University of North Carolina, Charlotte}

DR. DAVID S. COTTRELL is an Assistant Professor in the Department of Engineering Technology, University of North Carolina at Charlotte. He graduated from the United States Military Academy in 1978 and retired in 2000 after more than 22 years of service with the US Army Corps of Engineers. Studies at Texas A\&M University resulted in an MS Degree in Civil Engineering in 1987 and a $\mathrm{PhD}$ in 1995. He is a registered Professional Engineer and has taught courses in statics, dynamics, mechanics of materials, graphic communications, engineering economy, and construction planning, scheduling, estimating, and management.

\section{Chung-Suk Cho, University of North Carolina, Charlotte}

DR. CHUNG-SUK CHO is an Assistant Professor at the University of North Carolina at Charlotte, Department of Engineering Technology. His teaching and research focus on project scope definition, pre-project planning, sustainable construction, project administration, construction safety, construction simulation, and project management. He has prior teaching experience at North Carolina A\&T State University in construction management and working experience with Fluor Corporation as a project manager. 


\section{Integrating Green Engineering into a Multi-Disciplinary Seminar Course: Capitalizing on a Target of Opportunity}

\section{Introduction}

This paper describes the innovative development of a seminar course in a program that effectively blends two undergraduate Bachelor Degrees - in Civil Engineering Technology and in Construction Management. In a bold attempt to foster unity within the student body, this seminar course is mandatory for all students within the program regardless of major or year classification. The course provides a unique opportunity for older students to serve as role models and mentors for younger students and to consequently aid in development of esprit and collegiality among the members of this relatively new program.

Since all students take this course each spring, the topics covered must change from year to year to prevent redundancy for returning students. Professors tailor the course coverage and redefine associated learning outcomes to match current issues and relevant subjects particularly germane to the needs of the students, responsive to the current state of the industry, and consistent with the expertise and research talents of the faculty. Presentations and class work include traditional instruction and extensive writing with guest lecturers periodically providing the voice of industry as a touch of reality. This paper focuses on the most recent complete semester where sustainable construction emerged as the new course focus.

\section{Background}

Traditionally, the focus of construction education in the United States has been on the management issues, materials, methods, and technical aspects of construction. Environmental concerns or issues were thought to be the problem of architect, thus, received less attention in construction curriculum. ${ }^{1}$ However, various organizations, from the United Nations to contractor associations, have called for green and sustainable practices to be integrated into the construction curriculum, and various approaches have been tried at different institutions.

With increased global concerns regarding environmental degradation, declining natural species, and global warming, there has been an accelerated movement toward increasing the sustainability of the built environment. One of the most obvious indicators of this increased concern is the tremendous expansion of the United States Green Building Council (USGBC) and its Leadership in Energy and Environmental Design (LEED) program, a voluntary standard for sustainable buildings in which certification occurs upon meeting specified criteria. ${ }^{2}$ According to the USGBC, their membership has increased ten-fold since 2000 and the value of green building construction exceeded $\$ 12$ 
billion in 2007. From relative obscurity just a decade ago, green and sustainable practices are now significant issues in both the construction industry and construction education. With this explosion comes an increasing need for construction managers with knowledge in the various aspects of sustainable green building. To produce construction graduates who meet this need, it is necessary to retool programs so that they incorporate green philosophies and techniques. ${ }^{3}$

Sustainable construction management is a complex subject cutting across many different disciplines. The teaching of sustainability issues in construction is currently being achieved fragmentally, and lacks broadness and depth in terms of the issues covered. ${ }^{4}$ In fact, many universities are integrating green education into their construction curriculum either by incorporating green ideas into existing courses such as materials/methods or mechanical/electrical courses or by creating new courses that focus primarily on sustainable ideas. ${ }^{5}$ Some of the universities that are in the forefront of providing green education are listed as below.

\begin{tabular}{|c|c|c|}
\hline University & Course & Content \\
\hline Pennsylvania State University & $\begin{array}{c}\text { Sustainable } \\
\text { Building Methods }\end{array}$ & Sustainable and green design \\
\hline The University of Florida & $\begin{array}{l}\text { High-Performance } \\
\text { Green building } \\
\text { delivery systems }\end{array}$ & $\begin{array}{l}\text { Overview of high performance } \\
\text { green buildings, LEED criteria } \\
\text { discussed in detail }\end{array}$ \\
\hline Colorado State University & $\begin{array}{l}\text { Sustainable } \\
\text { Practice }\end{array}$ & $\begin{array}{l}\text { Design and construction, covers } \\
\text { design, construction, energy, \& } \\
\text { economic issues }\end{array}$ \\
\hline Texas A\&M University & $\begin{array}{l}\text { Sustainable } \\
\text { Construction }\end{array}$ & $\begin{array}{l}\text { Sustainable construction methods } \\
\text { and materials with an international } \\
\text { perspective }\end{array}$ \\
\hline Southern Polytechnic University & $\begin{array}{l}\text { Sustainable } \\
\text { Construction }\end{array}$ & $\begin{array}{l}\text { LEED certifications and related } \\
\text { issues }\end{array}$ \\
\hline Carnegie Mellon University & Sustainability & $\begin{array}{l}\text { Concept, overview, attitudes and } \\
\text { values }\end{array}$ \\
\hline Virginia Tech University & $\begin{array}{l}\text { Sustainable } \\
\text { Facility System }\end{array}$ & $\begin{array}{l}\text { Introduces means, methods, and } \\
\text { analytical practices associated with } \\
\text { sustainable built environment }\end{array}$ \\
\hline
\end{tabular}

\section{The Course: A Green Iteration in Professional Development}

This professional development course has continued to evolve and is currently covering "Information Technology in Construction," as it applies to construction, business and information management, Computer Aided Design (CAD) and 
visualization, cost estimating, planning, scheduling, and facilities management. Nevertheless, this paper focuses on the most recent completed iteration where it presented sustainable construction as the course focus. Due to the nature of the seminar, a course text is not always prescribed, but the technical nature of green engineering necessitated the adoption of Sustainable Construction - Green Building Design and Delivery. ${ }^{6}$ Associated learning objectives noted below were developed to foster an understanding of professional issues related to green engineering and sustainability in civil engineering and construction. By the end of the course students were able to:

- Define green engineering and sustainability,

- Independently research issues related to green engineering and sustainability in construction,

- Discuss global and societal issues related to green engineering and sustainability, and

- Recognize the importance of life-long professional development through networking opportunities with regional construction and engineering industry professionals.

Supporting these objectives, course lectures were developed that presented a variety of topics that challenged students' perception on many traditional opinions and construction practices and materials with innovative approaches developed to "recycle, reuse, and reduce." Course lectures included

- Green Engineering \& Sustainability Overview

- Ecological Design Fundamentals

- Green Building Assessment and Construction Operations

- Sustainable Building Energy Systems

- Sustainable Sites and Land Development

- The Building Hydrologic System

- Green Building Delivery Systems \& Processes

- Green Building Materials and Product

- The Cutting Edge and Beyond: Future Trends in Green Engineering

A critical factor contributing to the success of this program, guest speakers practicing professionals from industry - augmented classroom lectures with current, real examples of how green engineering impacts the way we do business and how we approach basic tenets of design, engineering, construction, and the global environment. These presentations were engaging and highly effective in moving "Green" educational material out of the abstract and into a practical, relevant setting. For this course, the guest speakers included 
- Chris Carlson, Whiting-Turner Company, Topic: "LEED in the Institutional/Educational Sector"

- Chris Butlak, R.T. Dooley Construction, Topic: "Sustainable Construction \& LEED Professional Accreditation"

- Lisa J. Beckstrom, S\&ME, Inc., Topic: "Sustainable Land Development Practices"

- George Galambos, McKim \& Creed, Topic: "Water Reuse \& Sustainability in Public Works"

- Ed Maher, Turner Construction Company, Topic: "Implementing LEED in the Commercial Construction Sector"

\section{Student Assessment}

Student feedback on all courses are collected at the end of each semester through questionnaires and written response forms. Students are asked a wide range of questions concerning principally the effectiveness of the professor and the relevancy of the course. In all categories, student ratings tracked above the norm for both the college and the University - they really liked the course and all of its particulars. Student written comments punctuated this feedback. Students were apparently primarily excited about the immediate relevancy of the material and its timely presentation. In some cases, students followed this course over the summer break by pursuing LEED certification as this course apparently served to open up new career opportunities. Representative student comments included the following:

- "Wish all professional development courses were this involved!"

- "Very Helpful to CM Majors!"

- "Course is very beneficial."

- "Very interesting - I love LEED!"

\section{Conclusion}

Although generally considered a "non-technical" course, this paper presents this seminar as a critical target of opportunity to arm students with information on timely, relevant topics pertinent to their success as students and as future practicing engineers. Although the course itself has now progressed on to other topics, this paper documents the benefits of a professional development course that exhibits a unique level of flexibility. The iterative course format ensures relevance and freshness in a course that may often tend toward stale and predictable. This paper describes a structured, multidisciplined seminar where students from different majors as well as different years can interact and benefit from each other's diverse perspectives as well as topics chosen from today's global environment. Assessment seems to confirm that this was a target of opportunity that was well met. 


\section{References:}

1. Tinker, A. \& R. Burt (2002), "Greening the Construction Curriculum," ASC Proceedings of the $39^{\text {th }}$ Annual Conference, 113-118.

2. Ibid.

3. Ibid.

4. Dyer, T.D. \& Y. Xing (2007), "Developing e-Learning Materials for Sustainable Construction Management," Final Department of Civil Engineering Report TDYX001.

5. Mead, S. P. (2001), "Green building: Current status and implications for construction education," ASC Proceedings of the $37^{\text {th }}$ Annual Conference, 169178.

6. Charles J. Kibert (2008), Sustainable Construction - Green Building Design and Delivery, $2^{\text {nd }}$ Edition, John Riley \& Sons, Inc. Hoboken, New Jersey. 